\title{
Evaluation of fecal indicators for assessing energy and nitrogen status of cattle and goats
}

\author{
GREGORIA NUNEZ-HERNANDEZ, JERRY L. HOLECHEK, DAVID ARTHUN, \\ ACKIM TEMBO, JOE D. WALLACE, MICHAEL L. GALYEAN, MANUEL CARDE- \\ NAS, AND RAUL VALDEZ
}

Authors are graduate research assistant, professor, graduate research assistants, and professors, Dept. of Animal and Range Sciences, New Mexico State University, Las Cruces; professor, Dept. of Experimental Statistics, New Mexico State University; and professor, Dept. of Fishery and Wildlife Sciences, New Mexico State University.

\begin{abstract}
In vivo digestibility trials involving cattle (steers) and goats (wethers) fed shrub and nonshrub mixtures were conducted to evaluate the potential of fecal output, fecal nitrogen output, and fecal nitrogen percent for assessing diet intake, nitrogen balance, and digestibility. Two cattle digestion trials involving 8 feeds and 4 goat digestion trials involving 13 feeds were used to develop simple linear and multiple regression equations between fecal and diet characteristics. Crude protein percent (organic matter basis) of cattle diets ranged from 3.9 to $12.0 \%$; that of goats ranged from 7.5 to $14.4 \%$. Low-phenolic and high-phenolic shrubs were fed in separate diets to goats while cattle diets involved only low-phenolic shrubs. Fecal output of organic matter (percentage of body weight) was correlated $\left(r^{2}>0.80\right)$ with forage organic matter intake (percentage of body weight) for both cattle and goats when all feeds were included in the regression. Linear regression intercepts, but not slopes, differed $(P<0.05)$ among cattle and goats. Multiple regression equations did not improve evaluation of forage intake over simple linear equations using fecal output. Fecal nitrogen output (g N/kg BW) was associated more closely with nitrogen balance ( $\mathrm{g} \mathrm{N} / \mathrm{kg} \mathrm{BW}$ ) than other fecal indicators. Further, fecal $\mathrm{N}$ output was best associated with nitrogen balance for both cattle and goats ( $r^{2}=0.64,73$, respectively) when used in multiple regression equations. Multiple regression equations showed potential for evaluating nitrogen intake ( $\mathrm{g} \mathrm{N} / \mathrm{kg} \mathrm{BW}$ ) of both cattle and goats, $\left(R^{2}=0.91,0.87\right.$, respectively). Although it is doubtful that our equations have broad applications, our approach might be useful if specific equations were developed for individual range types.
\end{abstract}

Key Words: ruminants, rangelands, forages, native shrubs

Because of the high labor demand, high cost, and low precision associated with the use of fistulated animals (Holechek et al. 1982), fecal indices have received considerable attention for assessing nutritional status of range ruminants. Reliability of fecal indices for monitoring range ruminant nutritional status has been a controversial subject (Hobbs 1987, Leslie et al. 1987).

Fecal indicators with the most potential to evaluate grazing ruminant energy and protein status include fecal nitrogen concentration (Gates and Hudson 1981, Holechek et al. 1982, Squires and Siebert 1983); total fecal nitrogen output (Stallcup et al. 1975); and total fecal output (Mertens 1973, Holechek et al. 1985). The objective of our study was to evaluate the potential of these 3 parameters for assessing important diet nutritional characteristics of cattle and goats using several different diets comprised of common range grasses, forbs, and shrubs.

Journal Article 1418 of the New Mexico Agr. Exp. Sta., Las Cruces.

Manuscript accepted 10 July 1991.

\section{Materials and Methods}

\section{Cattle Trials}

Two digestion trials involving cattle were conducted in the temperature-controlled (approximately $22^{\circ} \mathrm{C}$ ) metabolism laboratory at New Mexico State University during summer 1986 through fall 1987. These trials involved Hereford $\times$ Angus steers $(\bar{x}$ $w t=213 \mathrm{~kg}$ ) reared on desert grassland range in southcentral New Mexico. Conventional digestion stalls and a $4 \times 4$ latin square design were used in both trials. From a practical standpoint the 2 trials represent a logistic organization and involve 8 diets with each diet fed to 4 different steers.

Blue grama hay (Bouteloua gracilis [H.B.K.] Lag. Ex. Griffiths) and barley straw (Hordeum vulgare L.) served as the basal diets in trials 1 and 2, respectively. Native forbs, native shrubs, and alfalfa (Medicago sativa L.) hay were mixed with these basic feeds. Forbs and shrubs used for these experiments have been important in cattle diets from southern New Mexico rangelands. Forbs involved a 50:50 mixture of scarlet globemallow (Sphaeralcea coccinea [Nutt.] Rybd.) and leatherleaf croton (Croton corymbulosus Lam.), whereas shrubs were a 50:50 mixture of fourwing saltbush (Atriplex canescens [Pursh.] Nutt.) and mountain mahogany (Cercocarpus montanus Raf.). Current year's growth of these plants was hand-harvested from rangelands near Las Cruces, New Mexico during summer 1986. After air drying, these materials were ground to pass a $2.5-\mathrm{cm}$ screen. Blue grama hay and barley straw also were ground to pass a $2.5-\mathrm{cm}$ screen and mixed with either forbs, shrubs, or alfalfa.

In both trials, steers were fed ad libitum, and feed offered and orts were recorded and subsampled. Water was available free choice, but no salt was provided. Each trial lasted 15-days, with total collections of feces and urine obtained during the last 5-days. Feces from each steer were mixed thoroughly daily, and a $10 \%$ subsample was oven dried $\left(50^{\circ} \mathrm{C}\right.$ for $48 \mathrm{~h}$ ) and ground to pass a 2 -mm screen. Total urine output was collected in vessels containing $10 \mathrm{ml}$ of $6 \mathrm{~N} \mathrm{HCL}$. A $100-\mathrm{ml}$ subsample was obtained daily, stored at $-20^{\circ} \mathrm{C}$ and later pooled by steer within period.

Chemical analyses were performed on samples of feed, orts, feces, and urine for each steer and feed combination in each trial. Dry matter, organic matter, and total nitrogen were determined by standard procedures (AOAC 1984). Acid detergent fiber, neutral detergent fiber, and acid detergent insoluble nitrogen analyses were performed by nonsequential procedures of Goering and Van Soest (1970). Chemical composition of the diet consumed was estimated from the chemical composition and amount of feed offered and chemical composition and amount of orts. Detailed descriptions of these trials including chemical analyses of feeds, diets, and feces are provided by Arthun et al. (1992). 
Table 1. Linear regression coefficients for predicting nutritional characteristics of steer and goat diets using fecal organic matter output as a percentage of body weight as the independent variable.

\begin{tabular}{|c|c|c|c|c|c|c|}
\hline Animal & Type of diet & Dependent variable! & Equation & $\mathbf{n}$ & $r^{2}$ & Sy.x \\
\hline Steer & All & OMI (\% BW) & $y=0.45+1.80 x$ & 32 & $0.81^{* *}$ & 0.16 \\
\hline Goat & All & OMI (\% BW) & $y=0.16+1.77 x$ & 48 & $0.86^{* *}$ & 0.24 \\
\hline Steer & All & DOMI (\% BW) & $y=0.48+0.74 x$ & 32 & $0.44^{* *}$ & 0.15 \\
\hline Goat & All & DOMI (\% BW) & $y=0.20+0.82 x$ & 48 & $0.74^{* *}$ & 0.16 \\
\hline Steer & All & DOM \% & $y=72.66-19.77 x$ & 32 & $0.47^{* *}$ & 3.86 \\
\hline Goat & All & DOM \% & $y=60.17-6.66 x$ & 48 & $0.32 *$ & 3.31 \\
\hline Steer & Grass & $\mathrm{NB}(\mathrm{gN} / \mathrm{kg} \mathrm{BW})$ & $y=-0.11+0.26 x$ & 8 & $0.63^{*}$ & 0.04 \\
\hline Goat & All & $\mathrm{NB}(\mathrm{gN} / \mathrm{kg} \mathrm{BW})$ & $y=-0.12+0.16 x$ & 48 & $0.59 * *$ & 0.05 \\
\hline Steer & Grass & $\mathrm{NI}(\mathrm{gN} / \mathrm{kg} \mathrm{BW})$ & $y=-0.11+0.47 x$ & 8 & $0.91^{* *}$ & 0.03 \\
\hline Steer & Shrub & $\mathrm{NI}(\mathrm{gN} / \mathrm{kg} \mathrm{BW})$ & $y=0.13+0.27 x$ & 16 & $0.76^{* *}$ & 0.02 \\
\hline Goat & All & $\mathrm{NI}(\mathrm{gN} / \mathrm{kg} \mathrm{BW})$ & $y=0.001+0.34 x$ & 48 & $0.79 * *$ & 0.06 \\
\hline Steer & Grass & СР\% & $y=-0.37+11.54 x$ & 8 & $0.82^{* *}$ & 1.00 \\
\hline Steer & Forb & $\mathrm{CP} \%$ & $y=11.78-0.11 x$ & 8 & $0.75^{* *}$ & 1.01 \\
\hline Goat & All & $\mathrm{CP} \%$ & $y=7.91+1.90 x$ & 48 & 0.18 & 1.37 \\
\hline
\end{tabular}

*Significant $P<0.05$

* Significant $P<0.05$.
* Significant $P<0.01$

IOMI = Organic matter intake (\% body weight), DOMI = Digestible organic matter intake (\% body weight), NB = Nitrogen balance, NI = Nitrogen intake, $\mathrm{CP}=\mathrm{Crude}$ protein.

\section{Goat Trials}

Four digestion trials involving wether Angora goats reared on shrubland range in southcentral New Mexico also were conducted in the metabolism laboratory at New Mexico State University during summer, 1986, through fall, 1988. Each trial was conducted in conventional digestion stalls. In trials 3 through 5,12 goats $(\bar{x}$ wt $=41 \mathrm{~kg}$ ) assigned randomly to the 3 feeds ( 4 goats per feed) were used in each trial. From a practical standpoint the goat study involved 13 feeds with each feed fed to 4 different goats.

In Trial 6, 16 goats were randomly assigned to 4 different feeds (4 goats per feed). Trials 3, 4, and 5 evaluated 1 high phenolic shrub diet, 1 low phenolic shrub diet, and an alfalfa control diet, respectively. Leaves from big sagebrush (Artemisia tridentata Nutt. ssp. tridentata), gray oak (Quercus grisea Liebm.), true mountain mahogany, fourwing saltbush, common winterfat (Ceratoides lanata [Pursh.] J.T. Howell), and one-seed juniper (Juniperus monosperma [Engelm.] Sarg.) were collected from various ranges in New Mexico. Leaves from mountain mahogany and fourwing saltbush were collected in spring, 1986; leaves from the other 4 shrubs were collected in winter, 1986 . In all cases, plant collection consisted of current year's annual growth of leaves. Leaves were air-dried before use. The same barley straw and blue grama hay used in trials 1 and 2 with cattle were used in goat trials.

In all trials, goats were fed ad libitum, and feed offered and orts were recorded and subsampled. Water was available free choice, but no salt was provided. Each trial consisted of a 10-day adjustment period followed by 4-days of total fecal and urine collection. Fecal and urine samples were handled as those were in cattle trials.

Chemical analyses performed on samples of feed, orts, feces, and urine were the same as in trials 1 and 2 . In addition, ether extract was determined by standard procedures (AOAC 1984). Tannin content of feeds was determined by the modified vanillin $/ \mathrm{HCl}$ procedure (Burns 1971 and Price et al. 1978) as modified by Price et al. (1978). Total phenolic content was measured according to the Folin-Denis procedure (AOAC 1984). Chemical composition of the diet consumed was determined using the same procedures as for cattle in trials 1 and 2. Detailed descriptions of feeds and chemical analyses for feed, diets, and feces are given by NunezHernandez et al. (1989) for trials 3, 4, and 5 and Boutouba et al. (1990) for trial 6.

\section{Statistical Analyses}

Simple linear regression and correlation analyses were used to determine relationships between diet types and combined diets for each animal species. Slope and y intercept coefficient differences among diets were evaluated $(P<0.05)$ using procedures of Neter and Wasserman (1974). Stepwise regression analyses were then conducted using all independent variables, quadratic effects, and interactions among variables $(P<0.05)$ for each animal species using all diets (SAS 1984).

\section{Results and Discussion}

\section{Forage Intake}

Forage intake by both cattle and goats was correlated highly with total fecal output when all feeds were used in regressions (Table 1, Figure 1). Multiple and curvilinear regression equations using fecal output to predict intake did not improve fit of data over simple linear equations (Table 1). Our results are consistent with Holechek et al. (1985) using cattle and Mertens (1973) using sheep, who found that fecal output was associated closely with forage intake.

Our results are inconsistent with those of Conrad et al. (1964)

$$
\begin{aligned}
& + \text { Goats } \\
& \text { - Steers }
\end{aligned}
$$

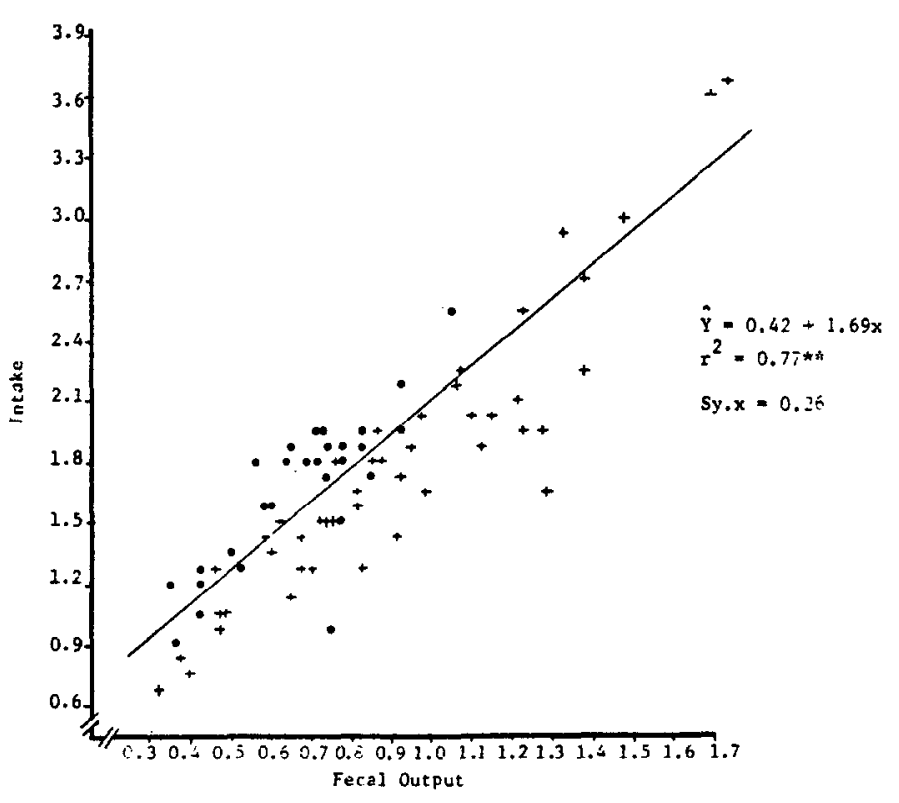

Fig. 1. Relationship between organic matter intake (\% body weight) and fecal output (organic matter/\% body weight) for cattle and goats using all feeds. 
Table 2. Linear regression coefficients for predicting nutritional characteristics of steer and goat diets using fecal nitrogen output (g N/kg BW) as the independent variable.

\begin{tabular}{|c|c|c|c|c|c|c|}
\hline Animal & Type of diet & Dependent variable ${ }^{1}$ & Equation & $\mathbf{n}$ & $r^{2}$ & Sy.x \\
\hline Steer & Grass & $\mathrm{NI}(\mathrm{gN} / \mathrm{kg} \mathrm{BW})$ & $y=-0.09+28.11 x$ & 8 & $0.88^{*}$ & 0.03 \\
\hline Steer & Shrub & $\mathrm{NI}(\mathrm{gN} / \mathrm{kg} \mathrm{BW})$ & $y=0.10+15.95 x$ & 16 & $0.78^{* *}$ & 0.02 \\
\hline Goat & Low phenolic & $\mathrm{NI}(\mathrm{gN} / \mathrm{kg} \mathrm{BW})$ & $y=0.04+24.91 x$ & 26 & $0.82^{* *}$ & 0.06 \\
\hline Goat & High phenolic & $\mathrm{NI}(\mathrm{gN} / \mathrm{kg} \mathrm{BW})$ & $y=0.04+16.14 x$ & 22 & $0.86^{* *}$ & 0.04 \\
\hline Steer & Grass & $\mathrm{NB}(\mathrm{gN} / \mathrm{kg} \mathrm{BW})$ & $y=-0.09+14.41 x$ & 8 & $0.52^{*}$ & 0.04 \\
\hline Goat & All & $\mathrm{NB}(\mathrm{gN} / \mathrm{kg} \mathrm{BW})$ & $y=-0.10+10.17 x$ & 48 & $0.62^{* *}$ & 0.04 \\
\hline Steer & All & OMI (\% BW) & $y=0.74+69.75 x$ & 32 & $0.55^{* *}$ & 0.24 \\
\hline Goat & Low phenolic & OMI (\% BW) & $y=0.36+124.76 x$ & 26 & $0.87^{* *}$ & 0.24 \\
\hline Goat & High phenolic & OMI (\% BW) & $y=0.49+86.44 x$ & 22 & $0.75^{* *}$ & 0.32 \\
\hline Steer & All & DOMI (\% BW) & $y=0.60+28.70 x$ & 32 & $0.30^{* *}$ & 0.17 \\
\hline Goat & Low phenolic & DOMI (\% BW) & $y=0.28+60.09 x$ & 26 & $0.85^{* *}$ & 0.12 \\
\hline Goat & High phenolic & DOMI (\% BW) & $y=0.34+40.16 x$ & 22 & $0.63^{* *}$ & 0.20 \\
\hline Steer & All & DOM \% & $y=70.14-820.97 x$ & 32 & $0.37^{* *}$ & 4.21 \\
\hline Goat & All & DOM \% & $y=58.78-364.42 x$ & 48 & $0.26^{* *}$ & 3.43 \\
\hline
\end{tabular}

* Significant $P<0.05$.

* Significant $P<0.01$

${ }^{1} \mathrm{NI}=$ Nitrogen intake, $\mathrm{NB}=$ Nitrogen balance, $\mathrm{OMI}=$ Organic matter intake, DOMI $(\%$ BW) Digestible organic matter intake, DOM Digestible organic matter.

who reported that fecal output was relatively constant and not associated with forage intake when roughage concentrate diets ranging from 52 to $67 \%$ in dry matter digestibility were fed to dairy cows. The fact that concentrates (grains) were used in the Conrad et al. (1964) study may explain why their results are inconsistent with studies that have involved only forages.

Our results indicate that fecal output is a good indicator of forage intake by ruminants and that specific regression differences among ruminant species may be small. Presently, accurate estimation of in vivo digestibility is a greater problem in range nutrition studies than measurement of fecal output. Based on our research we believe fecal output values should be presented along with forage intake estimates when data from range nutrition studies are published. Although more research is needed, it appears that fecal output can be a useful indicator of forage intake through the range of forage digestibilities observed in our study (46 to $64 \%$ OM digestibility). However, specific equations are desirable for individual range types and classes of animals.

Between diet variation in in vivo organic matter digestibility was much less than that for fecal organic matter output (\% BW). The coefficients of variation for in vivo organic matter digestibility values were 6.0 and $6.4 \%$ for cattle $(n=8)$ and goats $(n=13)$, respectively, compared to $25.6 \%$ (both animals) for fecal organic matter output (\% BW). In our study, in vivo organic matter digestibility was negatively associated with forage organic matter intake for cattle $(r=-0.91, \mathrm{n}=8)$ and showed no association with forage organic matter intake (\% BW) for goats $(r=0.29, \mathrm{n}=13)$. Both our study and that of Holechek et al. (1985) showed in vivo digestibility responds erratically to changes in intake when ruminant diets change between different types of forages. This is because forbs and shrubs typically have shorter retention times due to less cell wall but greater lignification than grasses (Ingalls et al. 1966, Milchunas et al. 1978, Spalinger et al. 1986). Lignification reduces cell wall digestibility (Van Soest 1982). Grass diets are typically characterized by higher digestibilities due to less lignification but lower intake due to higher fiber levels than diets containing forbs and shrubs (Ingalls et al. 1966, Spalinger et al. 1986). Fecal organic matter output (\% BW) reflects both intake and digestibility influ-

Table 3. Best regression coefficients for predicting nutritional characteristics of steer and goat diets using fecal nutritional characteristics of FO (\% BW), FNO (gN/kgBW) and FN (\%) as independent variables and diet type1.

\begin{tabular}{|c|c|c|c|c|c|}
\hline Animal & Dependent variable & Equation & $\mathbf{n}$ & $r^{2}$ & Sy.x \\
\hline Steer & OMI (\% BW) & $y=0.45+1.80 F 0$ & 32 & $0.81 * *$ & 0.16 \\
\hline Goat & OMI (\% BW) & $y=0.94+0.89 \mathrm{~F}^{2}$ & 48 & $0.86^{* *}$ & 0.24 \\
\hline Steer & $\mathrm{NB}(\mathrm{gN} / \mathrm{kg} \mathrm{BW})$ & $y=-0.22+42.6 \mathrm{FNO}-1339.97 \mathrm{FNO}^{2}$ & 32 & $0.64^{* *}$ & 0.03 \\
\hline Goat & $\mathrm{NB}(\mathrm{gN} / \mathbf{k g ~ B W})$ & $\begin{aligned} \mathrm{y}= & -0.20+27.59 \mathrm{FNO}-547.37 \mathrm{FNO}^{2}- \\
& 123.88 \mathrm{FNO}^{2} \mathrm{xl}\end{aligned}$ & 48 & $0.73^{* *}$ & 0.04 \\
\hline Steer & NI (gN/kg BW) & $\begin{aligned} y= & -0.26+65.47 \mathrm{FNO}-1643.08 \mathrm{FNO}^{2}- \\
& 160.02 \text { FN } 0 \times 3\end{aligned}$ & 32 & $0.91^{* *}$ & 0.03 \\
\hline Goat & NI (gN/ kg BW) & $\begin{aligned} y= & -0.19+0.34 F 0+0.17 F N- \\
& 674 F N 0 x\end{aligned}$ & 48 & $0.87^{* *}$ & 0.05 \\
\hline Steer & DOMI (\% BW) & $y=0.48+0.74 F 0$ & 32 & $0.44^{* *}$ & 0.15 \\
\hline Goat & DOMI (\% BW) & $y=0.20+0.82 \mathrm{~F} 0$ & 48 & $0.74^{* *}$ & 0.16 \\
\hline Steer & DOM \% & $y=66.56-14.87 \mathrm{FO}^{2}$ & 32 & $0.47 * *$ & 3.85 \\
\hline Goat & DOM \% & $\begin{aligned} y= & 103.21-69.62 F N-2.29 F 0^{2}+25.89 \\
& F^{2}-14723.44 T^{2} N^{2} x\end{aligned}$ & 48 & $0.55^{* *}$ & 2.79 \\
\hline Steer & СР\% & $\begin{aligned} y= & 11.65-21.52 \times 1+48.83 F 0 \times 1-33.48 \\
F\left(0^{2} \times 1\right. & \end{aligned}$ & 32 & $0.84 * *$ & 0.48 \\
\hline Goat & СР\% & $y=8.93+110.86$ FNO $-1.53 x$ & 48 & $0.37^{* *}$ & 1.22 \\
\hline
\end{tabular}

$|x|=1$ when diet $=$ grass and 0 otherwise.

$\mathbf{x} 2=1$ when diet $=$ shrub and 0 otherwise.

$\mathrm{x} 3=1$ when diet $=$ forb and 0 otherwise.

**Significant at $P<0.01$.

OMI $(\% \mathrm{BW})=$ Organic matter intake $(\%$ body weight $), \mathrm{NB}=$ Nitrogen balance, $\mathrm{NI}=$ Nitrogen intake, DOMI = Digestible organic matter intake, $\mathrm{DOM}=\mathrm{Digestible}$ organic matter, $\mathrm{CP}=$ crude protein 


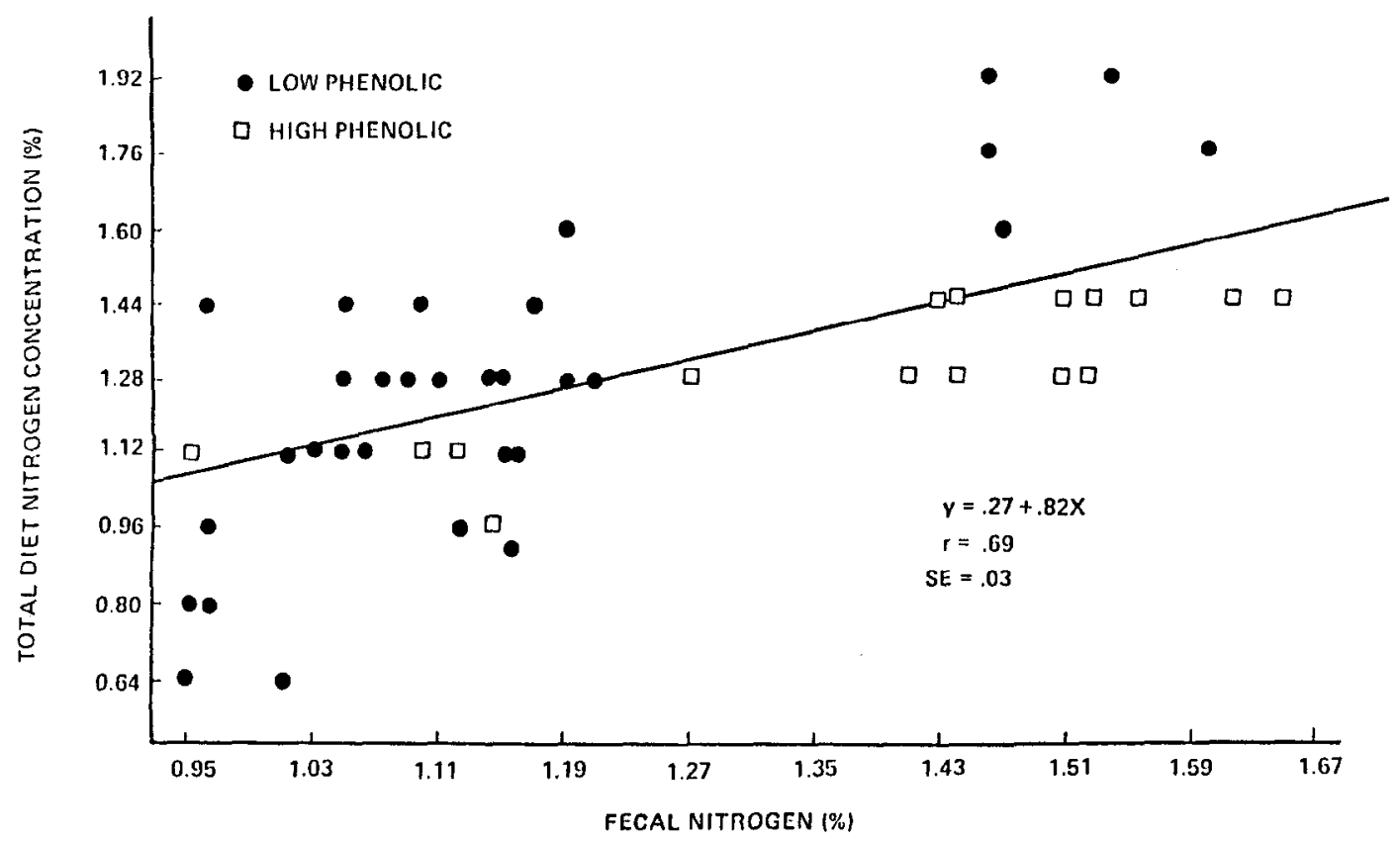

Fig. 2. Relationship between total diet nitrogen concentration and fecal nitrogen in combined diets.

ences on ruminant nutritional status. It may have limitations as an indicator of intake for diets that have exceptionally high or low in vivo digestibilities relative to their intake.

Other predictors of forage intake showed no advantages over single use of total fecal output in either simple linear regression equations or in multiple regression equations as an added variable with fecal output (Table 1). Some studies have shown that fecal N percent has potential for predicting ruminant forage intake (Cordova et al. 1978). In our data set, however, fecal nitrogen percent showed low correlations $\left(r^{2}<0.11\right)$ with intake for combined and individual diet types for both cattle and goats. Our study and those of Wofford et al. (1985) and Leite and Stuth (1990) show that fecal nitrogen percent is not correlated highly with forage intake by ruminants when the diet involves different types of forages.

\section{Protein}

Fecal output was associated more closely with nitrogen balance than other fecal indicators (Table 2). We consider coefficients of determination above 0.80 necessary for regression equations to have practical application; none of the equations met this standard.

Although nitrogen intake was associated with fecal nitrogen output and fecal output, simple linear regression equations differed among diet types, particularly for cattle. Multiple regression equations using data from all diets greatly improved prediction of nitrogen intake for both cattle and goat diets, and fecal nitrogen output was a key independent variable in these equations (Table 3).

Our study is consistent with Stallcup et al. (1975) in showing that fecal nitrogen output is a reliable indicator of nitrogen intake for ruminants consuming grass diets. However, when forbs and shrubs comprise part of the diet, fecal nitrogen concentrations can be elevated relative to diet nitrogen concentration (Mould and Robbins 1981, Wofford et al. 1985) because of protein-binding by phenolic/tannin compounds and the greater quantities of fiberbound nitrogen associated with these plants compared to grasses. Our data from goats (Table 2) show that high-phenolic diets have a different nitrogen intake to nitrogen output relationship than diets low in phenolics. The lower slope of the high phenolic equation for predicting nitrogen intake of goats reflects the elevated nitrogen output of the high compared to low phenolic diets.

Fecal nitrogen percent had low correlation $\left(r^{2}<0.25\right)$ with diet crude protein percent and regressions varied greatly with type of feed for both cattle and goats (Fig. 2). Our study confirms the concern expressed by Hobbs (1987) that fecal nitrogen percent is an unreliable indicator of diet crude protein concentration for different ruminants on the same range. Further, our research and that of Leite and Stuth (1990) show that fecal nitrogen percent lacks reliability for monitoring trends in nutritional status of a particular ruminant on the same range if their diet shows major shifts in botanical composition.

Digestible Organic Matter Intake and Organic Matter Digestibility

Fecal output was the only indicator that showed a consistent association $(P<0.05)$ with digestible organic matter intake for both animal species across all diets (Table 1); however, we do not consider the equations reliable. In vivo digestibility percent was not well correlated with any fecal indicator for either animal species. Our multiple regression equations for assessing in vivo digestibility percent had $S y \cdot x$ values too high for reliability (Table 3 ). Our study is consistent with Wofford et al. (1985) and Leite and Stuth (1990) in showing that fecal indicators have low potential for evaluating either in vivo digestibility or digestible organic matter intake.

\section{Experimental Limitations}

We believe our research has some important limitations that need to be recognized. The adjustment periods to the feeds may have been too short. In addition, the feeds were altered to some extent by chopping and drying. These factors could have altered some of the digestibility coefficients and their relationships with fecal indicators. Under field conditions diets would be more complex and change gradually through time. Several studies reviewed by Holechek et al. (1989) have shown fecal nitrogen concentration is well associated with range ruminant performance and nutritional status. Although our research shows that generalized equations for evaluating nutritional status based on fecal nitrogen concentration are unreliable, we still consider this a very useful tool for assessing nutritional status of ruminants on individual ranges if botanical composition of the diet is also evaluated. Knowledge of diet botanical composition can alert the investigator to potential 
problems that result from sharp dietary shifts or consumption of species high in tannins and volatile oils.

\section{Conclusions}

Our investigation evaluated the potential of fecal nitrogen percent fecal output and fecal nitrogen output as indicators of cattle and goat protein and energy status using diets containing forbs and shrubs fed under controlled conditions. Fecal output was associated well enough with forage intake for both cattle and goats to have potential in simple linear regression equations. It also showed correlations $(P<0.05)$ with nitrogen balance, nitrogen intake, and digestible organic matter intake. Our study shows that fecal output is a good indicator of grazing ruminant nutritional status, given the types of forages and range of digestibilites evaluated and provided that intake and digestibility are positively related. Although measurement of fecal output using bagged animals is laborious, new external markers have potential to reduce this problem without sacrificing accuracy (Pond et al. 1987).

Accurate measurement of in vivo digestibility is a serious problem for grazing ruminant nutritionists. None of the fecal indicators we studied showed any potential for evaluating in vivo digestibility. Based on other studies and our research, it is doubtful that in vivo digestibility can be evaluated accurately from fecal indicators.

Our results show fecal nitrogen percent has limitations as an indicator of ruminant protein status if sharp shifts occur in diet botanical composition or for comparisons between ruminant species grazing the same range. Under actual range conditions ruminant diets typically include a wide variety of species and change gradually. Several studies have shown fecal nitrogen concentration is a useful indicator of grazing ruminant nutritional status under these conditions. Our results do not invalidate these studies, but they do show that useful generalized equations across range types for nutritional assessments are unlikely.

\section{Literature Cited}

AOAC. 1984. Official methods of analysis (14th ed.). Assoc. Off. Analy. Chem. Washington, D.C.

Arthun, D., J.L. Holechek, J.D. Wallace, M.L. Galyean, M. Cardenas, and S. Rafique. 1992. Forb and shrub influences on steer nitrogen retention. J. Range Manage. (In press).

Boutouba, A., J.L. Holechek, M.L. Galyen, G. Nunez-Hernandez, J.D. Wallace, and M. Cardenas. 1990. Influence of two native shrubs on goat nitrogen status. J. Range Manage. 43:530-534.

Burns, R.E. 1971. Method for estimation of tannin in grain sorghum. Agron. J. 63:511-512.

Conrad, W., A.D. Pratt, and J.H. Hibbs. 1964. Regulation of feed intake in dairy cows. I. Change in importance of physical and physiological factors and increasing digestibility. J. Dairy Sci. 47:54-61.

Cordova, F.J., J.D. Wallace, and R.D. Pieper. 1978. Forage intake by grazing animals. A review. J. Range Manage. 31:430.
Gates, C.C., and R.J. Hudson. 1981. Weight dynamics of Wapiti in the Boreal forest. Act. Thericologica 26:467-518.

Goering, H.K., and J. Van Soest. 1970. Forage fiber analyses. USDA. ARS. Agr. Handbk. 379.

Hobbs, N.T. 1987. Fecal indices to dietary quality: a critique. J. Wildl. Manage. 51:317-321.

Holechek, J.L., M. Vavra, and R.D. Pieper. 1982a. Methods of determining the nutritive quality of range ruminant diets. A review. J. Anim. Sci. 53:291-302.

Holechek, J.L., M. Vavra, and D. Arthun. 1982b. Relationship between performance, intake and diet nutritive quality and fecal nutritive quality of cattle on mountain range. J. Range Manage. 35:741-744.

Holechek, J.L., M.L. Galyean, Helen Wofford, Dave Arthun, and Joe D. Wallace. 1985. Relationship between cattle forage intake and fecal physical characteristics. Nutr. Rep. Internat. 32:1294-1300.

Holechek, J.L., R.D. Pieper, and C.H. Herbel. 1989. Range management principles and practices. Prentice Hall Publ., Co., Englewood Cliffs, N.J.

Ingalls, J.R., J.W. Thomas, M.G. Tesar, and D.L. Carpenter. 1966. Relations between ad libitum intake of several forages and gut fill. J. Anim. Sci. 25:283-289.

Leite, E.R., and J.W. Stuth. 1990. Value of multiple fecal indices for predicting diet quality and intake of steers. J. Range Manage. 43:139-143.

Lestie, D.M., and E. Starkey. 1987. Fecal indices to dietary quality: a reply. J. Wildl. Manage. 51:321-323.

Mertens, D.R. 1973. Application of theoretical and mathematical models to cell wall digestion and forage intake in ruminants. Ph.D. Thesis, Cornell Univ., Ithaca.

Milchunas, M.G., M.I. Dyer, O.C. Wallmo, and D.E. Johnson. 1978. In vivo/in vitro relationships of Colorado mule deer forages. Colorado Div. Wildl. WRS-43.

Mould, E.D., and G.T. Robbins. 1981. Nitrogen metabolism in elk. J. Wild. Sci. 45:323-329.

Neter, J., and W. Wasserman. 1974. Applied linear statistical models. Richard D. Irwin, Inc. Homewood, Ill

Nunez-Hernandez, G., J.L. Holechek, J.D. Wallace, M.L. Galyean, A. Tembo, R. Valdez, and M. Cardenas. 1989. Influence of native shrubs on nutritional status of goats: nitrogen retention. J. Range Manage. 42:228-232

Pond, K.P., J.C. Burns, and D.S. Fisher. 1987. External markers-use and methodology in grazing studies. Proc. Grazing Livestock Nutr. Conf. p. 49-55. Univ. Wyoming.

Price, M.L., S. Van Scoyac, and L.G. Butler. 1978. A critical evaluation of the vanillin reaction as an assay in grain sorghum. Agr. Food Chem. 26:1214-1218.

SAS. 1984. SAS user's guide. Statistics. SAS Inst., Inc. Cary, N.C.

Spalinger, D.E., C.T. Robbins, and T.A. Hanley. 1986. The assessment of handling time in ruminants: the effect of plant chemical and physical structure on the rate of breakdown of plant particles in the rumen of mule deer and elk. Can. J. Zool. 64:312-321.

Squires, V.R., and B.D. Siebert. 1983. Botanical and chemical components of the diet and liveweight change in cattle on semi-desert rangeland in central Australia. Aust. Rangel. J. 5:28-34.

Stallcup, O.T., G.V. Davis, and L. Shields. 1975. Influence of dry matter and nitrogen intakes on fecal nitrogen losses. J. Dairy Sci. 58:1301-1308.

Van Soest, P.J. 1982. Nutritional ecology of the ruminant. $O$ and B Books Inc., Corvallis, Ore.

Wofford, H., J.L. Holechek, M.L. Galyean, J.D. Wallace, and M. Cardenas. 1985. Evaluation of fecal indices to predict cattle diet quality. J. Range Manage. 38:450. 